\title{
Aneta Niewęglowska, Lech Wyszczelski, W przededniu II wojny światowej. Wydawnictwo Naukowe UPH w Siedlcach, Siedlce 2018, ISBN: 9788370518882
}

https://doi.org/10.34739/his.2019.08.11

Tandem autorski A. Niewęgłowska i L. Wyszczelski wydał kolejne wspólne opracowanie $^{1}$. Tym razem książka dotyczy dziejów politycznych dwudziestolecia międzywojennego. Tytuł pracy jest trochę mylący, zbyt literacki, słowo „przeddzień” może sugerować, że chodzi o czas tuż przed wybuchem II wojny światowej, a tymczasem narracja zaczyna się od traktatu wersalskiego, czyli obejmuje cały okres międzywojenny. A zatem ów ,przeddzień” trwał 20 lat. Użyta w tytule formuła mogła posłużyć Autorom do szerszej refleksji na temat cezur pracy. Tymczasem we „Wstępie” i „Zakończeniu” Autorzy nie wzmiankują nawet problemu, zachowują kamienne milczenie w tej materii.

W poniższych uwagach nie będę wkraczał w merytoryczną zawartość pracy, pozostawiając ten obowiązek historykom zajmującym się dziejami powszechnymi dwudziestolecia międzywojennego. W tym miejscu chciałem sformułować kilka uwag dotyczących warsztatu naukowego Autorów.

Kilkustronicowe „Wstęp” i „Zakończenie” mają podobny charakter. Ten pierwszy zawiera krótką charakterystykę okresu międzywojennego, a „Zakończenie” to w zasadzie krótkie streszczenie pracy. We „Wstępie” brak próby sformułowania problemu badawczego, próby odpowiedzi na pytanie dlaczego takie, a nie inne problemy omówiono, jakimi zasadami kierowano się w doborze tematyki, dlaczego eksponowano te, a nie inne. Zarówno we „Wstępie”, jak i „Zakończeniu” Autorzy nie podjęli, choćby zdawkowej próby charakterystyki wykorzystanej literatury, a przecież ten okres posiada bardzo bogatą literaturę polską i obcojęzyczną. Nie omówili stanu badań nad poruszanymi problemami, ani słowem nie scharakteryzowali własnych poszukiwań badawczych. W związku z powyższym, jak sądzę, mogę przyjąć, że badania

\footnotetext{
* ORCID iD 0000-0003-1581-224X. jozef.pilatowicz@uph.edu.pl

${ }^{1}$ Poprzednie to: A. Niewęgłowska, L. Wyszczelski, Szkolnictwo wojskowe kadry zawodowej w Polsce do 1939 roku, Oświęcim 2014, por. moją recenzję w „Kwartalnik Historii Nauki i Techniki” 2015, nr 4, s. 185-196.
} 
oparto o literaturę zawartą w „Bibliografii (selektywnej)”. Ani w tym miejscu, ani we „Wstępie” i w „Zakończeniu” brak sformułowania zasad selekcji, co powinno być obowiązkiem w każdej pracy naukowej.

Całość „Bibliografii (selektywnej)” obejmuje, nie licząc publikacji źródeł i wspomnień, 41 pozycji, w tym 14 wydanych po 2000 r., w latach 80-tych - 13, 70-tych $-7,60$-tych -4 , 90-tych - 2, 50-tych - 1, 30-tych - 1. A zatem dominuje literatura wydana w PRL-u - 25 pozycji. Nie uwzględniając wydawnictw źródłowych i pamiętników, Autorzy podali tylko jedno opracowanie w języku obcym, angielskim A. Prażmowskiej. Jeśli przyjąć, że podana bibliografia odzwierciedla stan badań według Autorów, to oznacza, że dotarli z lekturą głównie do początków lat 90-tych XX w. Najczęściej występującym autorem w bibliografii jest L. Wyszczelski 6 pozycji na 41 ogółem. Nie umieszczono ani jednej pozycji A. Niewęgłowskiej, ponieważ Autorka nie zajmowała się dotychczas dziejami powszechnymi, co potwierdza wykaz publikacji ${ }^{2}$. Nie wzbogacają literatury przypisy, a to dlatego, że zamieszczono w nich pozycje $\mathrm{z}$ bibliografii.

W pewnym stopniu o lekceważącym stosunku Autorów do załączonej bibliografii, selektywnej zresztą, może świadczyć umieszczenie pracy L. Wyszczelskiego pt. Chmury nad Hiszpania (Warszawa 1987), wydanej w kieszonkowym formacie przez wydawnictwo MON w serii „Sensacje 20-wieku”. O ile pamiętam seria była skierowana do młodzieży. Nie jestem przeciwnikiem popularyzacji, ale, że zadam retoryczne pytanie, czy od 1987 r. nie opublikowano nic poważniejszego o tym okresie w Hiszpanii. Ale przede wszystkim omawiana publikacja A. Niewęgłowskiej i L. Wyszczelskiego miała być wynikiem badań naukowych, o czym zapewniają sami Autorzy zamieszczając na rewersie strony tytułowej następujące sformułowanie: „Wyniki badań, zrealizowane w ramach tematu badawczego nr 490/17/S, zostały sfinansowane z dotacji na naukę przyznanej przez Ministerstwo Nauki i Szkolnictwa Wyższego". Jeśli Autorzy umieścili w bibliografii naukowej książeczkę dla młodzieży pozbawioną całkowicie aparatu naukowego, to dlaczego zabrakło nowszych publikacji, uwzględniających archiwalia i najnowszą literaturę, w tym także popularnych książek Bogusława Wołoszańskiego, czy Piotra Zychowicza. Podczas selekcji z książeczką L. Wyszczelskiego przegrali nie tylko B. Wołoszański i P. Zychowicz, ale tacy wybitni historycy jak: Janusz Pajewski, Stanisław Sierpowski, Sławomir Dębski, Marek Kornat.

Wykaz literatury bardzo ważnej, w niektórych przypadkach kluczowej dla omówienia problemu, której Autorzy nie uwzględnili jest niezmiernie długi. Podam jedynie przykłady, aby unaocznić skalę braków. Ograniczę się do literatury polskiej

\footnotetext{
${ }^{2}$ Biblioteka UPH, [https://opac.uph.edu.pl/cgi-bin/wspd_cgi.sh/bibdnp.p].
} 
lub przetłumaczonej na język polski, dostępnej Autorom w momencie pisania pracy, czyli powiedzmy opublikowanej do 2015 r. włącznie.

Autorzy umieścili w bibliografii kilka zbiorów dokumentów, ale musieli zastosować wyjątkowy klucz selektywności, żeby nie zauważyć i nie docenić trzech opasłych tomów źródeł Stanisława Sierpowskiego ${ }^{3}$, znanego historyka o dużym dorobku naukowym, autora kilku prac dotyczących okresu międzywojennego, np. o faszyzmie i Lidze Narodów ${ }^{4}$. Wygląda to na niedocenienie dorobku S. Sierpowskiego, który padł ofiarą selekcji bez kryteriów, ponieważ nie chcę wierzyć w ignorancję Autorów zajmujących się od wielu lat naukowo dwudziestoleciem międzywojennym.

Kilka uwag bibliograficznych do poszczególnych rozdziałów, przy czym nie chodzi o kompletny wykaz, ponieważ bibliografia książek i artykułów jest ogromna, ale o dzieła podstawowe, które nawet przy bardzo ostrej selekcji powinny się ostać, albowiem stanowią trwały dorobek polskiej historiografii, a z bliżej nieznanych powodów zostały pominięte przez Autorów. Będą to tylko przykładowe publikacje, które zajmujący się dziejami powszechnymi dwudziestolecia międzywojennego powinni znać obowiązkowo.

W rozdziale pierwszym Ład Wersalski i jego ułomności brak pozycji Janusza Pajewskiego, wybitnego historyka, autora obszernych dzieł dotyczących pierwszej wojny światowej i odbudowy państwa polskiego ${ }^{5}$. Rozdział drugi Liga Narodów i niespetnione nadzieje na jej stabilizacyjna rolę $w$ świecie - brak pozycji S. Sierpowskiego (zob. przypis nr 4). Rozdział trzeci Faszyzm i jego wizja panowania w świecie pojęciem faszyzm Autorzy obejmują faszyzm włoski i nazizm, przy czym traktują je łącznie nie widząc różnicy, co w literaturze jest często podkreślane. Nie podjęli problemu zbieżności i różnic między stalinizmem i nazizmem. Brak tu jakiejkolwiek wzmianki o fundamentalnych dziełach na ten temat ${ }^{6}$.

\footnotetext{
${ }^{3}$ S. Sierpowski, Źródla do historii powszechnej okresu międzywojennego. T. 1. 1917-1926, Poznań 1989, T. 2. 1927-1934, Poznań 1992, T. 3. 1935-1939, Poznań 1992.

${ }^{4}$ S. Sierpowski, Faszyzm we Wtoszech 1919-1926, Wrocław 1972; S. Sierpowski, Miedzy wojnami 19191939. Cz. 1. Lata 1919-1929, Poznań 1998, Cz. 2. Lata 1929-1939, Poznań 1999; S. Sierpowski, Liga Narodów: powstanie, organizacja i zasady działania, Poznań 1984; S. Sierpowski, Liga Narodów w latach 1919-1926, Wrocław 2005; S. Sierpowski, Liga Narodów w najlepszym czasie (1926-1929), Poznań 2018.

${ }^{5}$ J. Pajewski, Odbudowa państwa polskiego, Warszawa 1978, wyd. 4 - 2005; J. Pajewski, Pierwsza wojna światowa 1914-1918, Warszawa 1991, 1998, 2004-2005, 2014;

${ }^{6}$ Np.: E. Jäckel, Hitlera poglą na świat, Warszawa 1973; E. Jäckel, Panowanie Hitlera: spetnienie światopogladu, Wrocław 1989; I. Kershaw, Hitler. T. 1, 1889-1936: hybris, Poznań 2001, T. 2 cz. 1. 1936-1941: nemezis, Poznań 2001, T. 2 cz. 2. 1941-1945, Poznań 2003; Stalinizm i nazizm: porównanie dyktatur. Pod red. I. Kershawa i M. Lewina, Gdańsk 2015. W bibliografii umieszczono tylko jedną pozycję J.W. Borejszy znawcy faszyzmu, zabrakło: J. W. Borejsza, Mussolini byt pierwszy ..., Warszawa 1979, 1989; J. Borejsza, Śmieszne sto milionów Stowian; wokót światopoglądu Adolfa Hitlera, Warszawa 2006, 2016.
} 
Rozdział czwarty poświęcono Kominternowi i idei Frontów Ludowych. Narracja skupia się na próbach utworzenia frontów ludowych w różnych krajach. W tym rozdziale tylko raz pada nazwisko Stalina, w tym i innych rozdziałach prawie nic nie dowiemy się o sytuacji wewnętrznej w ZSRR. Nie zauważyłem informacji o czystkach w armii radzieckiej, której śp. Paweł Piotr Wieczorkiewicz poświęcił obszerne dzieło (przeszło 1330 stron), ale Autorzy nie zauważyli tego opasłego tomu ${ }^{7}$. Nie zauważyłem nazwiska Trockiego (weryfikację utrudnia brak indeksu nazwisk, co nader sporadycznie współcześnie występuję i jest dziwne w dobie panowania komputerów) i jego permanentnej rewolucji, mającej w pewnym okresie istotne znaczenie dla polityki zagranicznej i armii radzieckiej. Brak też jakiejkolwiek biografii Stalina, a jest wiele dlatego zasygnalizuję jedynie Eugeniusza Duraczyńskiego ${ }^{8}$.

Jednym z największych zaskoczeń jest bibliografia do rozdziału Pakt Ribbentrop-Mołotow - taktyczny sojusz dwóch totalitaryzmów, w przypisach jedną z głównych ról przypadła W. T. Kowalskiemu ${ }^{9}$, a nie uwzględniono najnowszych, obszernych opracowań np. Sławomira Dębskiego i Marka Kornata, opartych o archiwalia i najnowszą literaturę ${ }^{10}$.

I tak można kontynuować rozdział po rozdziale, utwierdzając się w przekonaniu, że Autorzy po prostu nie uwzględnili najnowszej literatury historycznej, tzn. tej ukazującej się po 1990 r. Cezura ta ma istotne znaczenie dla historiografii polskiej i ukazywania się tłumaczeń autorów zagranicznych, ponieważ przestała funkcjonować cenzura. Zaskakuje zatem preferencja Autorów dla literatury powstałej w latach cenzury, a nader ograniczona dla literatury najnowszej, wolnej od cenzury, co miało istotne znaczenie, np. dla badań nad dziejami ZSRR.

Książka posiada dwóch autorów, którzy nie poinformowali o wkładzie w powstanie pracy każdego z nich. Moje zdziwienie dyktuje rzut oka na dotychczasowy dorobek naukowy A. Niewęgłowskiej. Otóż w Jej wykazie publikacji wśród 115 pozycji jedynie najwyżej trzy pozycje dotykają historii powszechnej dwudziestolecia międzywojennego ${ }^{11}$. Podnoszę tę kwestię ponieważ syntetyczne ujęcia pojawiają się zazwyczaj po wieloletnich badaniach, w tym przypadku dotyczących dziejów po-

\footnotetext{
${ }^{7}$ P. P. Wieczorkiewicz, Lańcuch śmierci: czystka w Armii Czerwonej 1937-1939, Warszawa 2001, 2916. Por. także tegoż autora: Sprawa Tuchaczewskiego, Warszawa 1994, 2012; Stalin i generalicja sowiecka w latach 1937-1941: sprawa Tuchaczewskiego i jej konsekwencje, Warszawa 1993.

${ }^{8}$ E. Duraczyński, Stalin: twórca i dyktator supermocarstwa, Pułtusk-Warszawa 2012.

${ }^{9}$ W.T. Kowalski, Ostatni rok Europy (1939), Warszawa 1989.

10 S. Dębski, Między Berlinem a Moskwa: stosunki niemiecko-sowieckie 1939-1941, Warszawa 2003, 2007; Kryzys 1939 roku w interpretacjach polskich i rosyjskich historyków. Pod red. S. Dębskiego i M. Narinskiego, Warszawa 2009; M. Kornat, Polska 1939 roku wobec paktu Ribbentrop-Molotow: problemy zbliżenia niemiecko-sowieckiego $w$ polityce zagranicznej II RP, Warszawa 2002; M. Kornat, Polityka równowagi 1934-1939. Polska między Wschodem a Zachodem, Kraków 2007; M. Kornat, Polityka zagraniczna Polski 1938-1939: cztery decyzje Józefa Becka, Gdańsk 2012.

${ }_{11}^{11}$ Biblioteka UPH, [https://opac.uph.edu.pl/cgi-bin/wspd_cgi.sh/bibdnp.p].
} 
wszechnych dwudziestolecia. Można podziwiać odwagę intelektualną Autorki, że bez własnych badań podjęła próbę współautorstwa pracy obejmującej problematykę np. faszyzmu, nazizmu, komunizmu, stosunków międzynarodowych, których Autorka dotychczas nie podejmowała.

Próbuję zrozumieć (choć nie zgadzam się z tego rodzaju postawą) przywiązanie L. Wyszczelskiego do literatury ostatniego ćwierćwiecza XX wieku, ale nie rozumiem A. Niewęgłowskiej reprezentującej średnie pokolenie historyków, która również jest przywiązana do tej samej literatury. Tandem autorski powinien odświeżyć i uzupełnić zestaw lektur.

Konkludując, książka nie spełnia rygorów pracy naukowej i nie powinna korzystać z finansowania wspierającego badania naukowe. Zakończę powyższe uwagi pytaniem retorycznym: czy recenzenci zauważyli powyższe mankamenty pracy?

I już zupełnie na koniec smutna konstatacja. Niestety, to nie pierwszy raz, i obawiam się, że nie ostatni, duet autorski zignorował najnowsze osiągnięcia historyków. To już staje się swoistą metodą, znakiem firmowym publikacji tej dwójki autorskiej. Utwierdza mnie w tym przekonaniu recenzja innej książki A. Niewęgłowskiej i L. Wyszczelskiego ${ }^{12}$ pióra Wojciecha Śleszyńskiego z Uniwersytetu w Białymstoku, który zarzuca Autorom: „skromny dobór źródeł i brak najnowszej literatury”, „nie uwzględniają najnowszej literatury przedmiotu”, praca „ukazuje stan badań i ustaleń naukowych z początku lat 90 . XX". W konkluzji recenzent podkreśla, że Autorzy ignorują fakt: ,... iż po upadku systemu komunistycznego uzyskaliśmy dostęp do nowych źródeł, które często w całkowicie innym świetle stawiają dotychczasową naszą wiedzę. Zastanawia sens wydania tego typu prac, które dając Czytelnikowi nieaktualny obraz dziejów, niczego nowego nie wnoszą do stanu naszej wiedzy"13. I co się zmieniło po trzech latach? Kompletnie nic, co zasygnalizowałem w swojej recenzji. Czy to koniec serii tego duetu autorskiego?

\footnotetext{
${ }^{12}$ A. Niewęgłowska, L. Wyszczelski, Obóz piłsudczykowski i jego wizje polityki wschodniej, Siedlce 2014. 13 „Biuletyn Historii Pogranicza” Pismo Oddziału Polskiego Towarzystwa Historycznego w Białymstoku, Nr 15, Białystok 2015, s. 96, całość recenzji s. 94-96.
} 